\title{
The East Asian Summer Monsoon at mid-Holocene: results from PMIP3 simulations
}

\author{
W. Zheng ${ }^{1}$, B. Wu ${ }^{1}$, J. He ${ }^{1,2}$, and Y. Yu ${ }^{1}$ \\ ${ }^{1}$ State Key Laboratory of Numerical Modeling for Atmospheric Sciences and Geophysical Fluid Dynamics, \\ Institute of Atmospheric Physics, Chinese Academy of Sciences, 100029, Beijing, China \\ ${ }^{2}$ Graduate University of Chinese Academy of Sciences, 100049, Beijing, China \\ Correspondence to: W. Zheng (zhengwp@mail.iap.ac.cn)
}

Received: 31 July 2012 - Published in Clim. Past Discuss.: 8 August 2012

Revised: 16 January 2013 - Accepted: 30 January 2013 - Published: 25 February 2013

\begin{abstract}
Ten Coupled General Circulation Models (CGCMs) participated in the third phase of Paleoclimate Modelling Intercomparison Project (PMIP3) are assessed for the East Asian Summer Monsoon (EASM) in both the pre-Industrial (PI, $0 \mathrm{ka}$ ) and mid-Holocene (MH, 6 ka) simulations. Results show that the PMIP3 model median captures well the large-scale characteristics of the EASM, including the two distinct features of the Meiyu rainbelt and the stepwise meridional displacement of the monsoonal rainbelt. At mid-Holocene, the PMIP3 model median shows significant warming (cooling) during boreal summer (winter) over Eurasia continent that are dominated by the changes of insolation. However, the PMIP3 models fail to simulate a warmer annual mean and winter surface air temperature (TAS) over eastern China as derived from proxy records. The EASM at MH are featured by the changes of largescale circulation over Eastern China while the changes of precipitation are not significant over its sub-domains of the Southern China and the lower reaches of Yangzi River. The inter-model differences for the monsoon precipitation can be associated with different configurations of the changes in large-scale circulation and the water vapour content, of which the former determines the sign of precipitation changes. The large model spread for the TAS over Tibetan Plateau has a positive relationship with the precipitation in the lower reaches of Yangzi River, yet this relationship does not apply to those PMIP3 models in which the monsoonal precipitation is more sensitive to the changes of large-scale circulation. Except that the PMIP3 model median captured the warming of annual mean TAS over Tibetan Plateau, no significant improvements can be concluded when compared with the PMIP2 models results.
\end{abstract}

\section{Introduction}

The mid-Holocene (MH, approximately $6000 \mathrm{yr} \mathrm{BP}$ (before present) is one of the widely studied periods in the Quaternary, which was characterised by a warmer period than present that is also known as Holocene Megathermal. The most important forcing at $\mathrm{MH}$ that differs from present is the enhanced seasonal contrast of incoming solar radiation at the top of atmosphere (Berger, 1978) that leads to a different climate condition. Therefore, it provides an opportunity to assess the ability of the Coupled General Circulation Model (CGCM), to understand the mechanisms in climate models and to contribute to the projection of the future climate changes.

The mid-Holocene has been a major period of foci in both the first and second phases of the Paleoclimate Modelling Intercomparison Project (PMIP). Fruitful results have been achieved in that the changes of insolation strengthened the summer monsoon systems in the Northern Hemisphere $(\mathrm{NH})$ and the ocean plays an important role in regulating the large-scale features of atmospheric circulations (Joussaume et al., 1999; Braconnot et al., 2000, 2007a,b; Zhao et al., 2005; Zheng and Braconnot, 2012). The numerical simulations show broad agreements with the reconstructions of proxy data that indicate an enhanced hydrological cycle and large-scale atmospheric circulation (Bartlein et al., 2011), and expansion of boreal forest at mid- and high latitudes of the Northern Hemisphere (Prentice et al., 2000). Studies of proxy data revealed that the Holocene megathermal reached a maximum during $7200-6000 \mathrm{yr}$ BP in China. The annual mean surface air temperature is about $1-4{ }^{\circ} \mathrm{C}$ higher than the present climate (Yao et al., 1991; Shi et al., 1993). Analysis of twelve atmosphere-ocean (AO) GCMs from PMIP2 
shows a warmer climate at $\mathrm{MH}$ that generally agreed with the pollen records over China (Wang et al., 2010). However, considerable model-data mismatch in the temperature over eastern China at MH has found (Jiang et al., 2012) that the PMIP1 and PMIP2 models failed to reproduce the warmerthan-present annual and winter climate conditions as derived from multi-proxy data for the MH (Shi et al., 1993; Yu et al., 1998, 2000; Ni et al., 2010). The large spread of model simulations in response to the insolation forcing at mid-Holocene exists among models.

The East Asian area is featured by a monsoonal climate. Due to the different thermal capacities of the continent and the ocean, warm low-pressure systems dominate over the continent during boreal summer and the subtropical high is located over the Northwest Pacific. The thermal contrast leads to prevailing southerly winds in summer and northerly winds in winter (Tao and Chen, 1987). Numerous studies have the characteristics of the East Asian Summer Monsoon well documented (e.g., Ding and Chan, 2005), however, it is still difficult for the CGCMs to realistically reproduce the distribution and magnitude of the summer precipitation in the East Asian monsoon areas (Zhao et al., 1995; Jiang et al., 2005; Zheng and Yu, 2009, 2013). The contributing factors to the EASM are more complex than those for the tropical monsoon systems, in which the Pacific and Indian Ocean SSTs and the snow cover over the Eurasia and the Tibetan Plateau are believed to be primary contributing factors to the activities of EASM (Ding and Chan, 2005). The EASM experienced a series of changes through the Holocene. At midHolocene, the enhanced EASM prevailed over eastern China with an increased precipitation about 40-100\% when compared with present observations (Yao et al., 1991; Shi et al., 1993). Evaluation shows that the PMIP2 models reproduced warmer and wetter summer climate conditions in East Asia at $\mathrm{MH}$, in which the precipitation was $5.8 \%$ higher (Wang et al., 2010). However, regional biases compared with the reconstructions and large spreads between models are found, in particular, over and around the Qinghai-Tibetan Plateau.

Inspired by previous work, the objective of this study is firstly to document basic features of the EASM from the PI simulations of PMIP3 models and compared with the present climate observations. And then the changes of EASM at MH are shown and compared with the results from PMIP2 models. The model spread in eastern China for the changes in monsoonal precipitation is discussed for a better understanding of the mechanisms for EASM changes at MH and the inter-model differences. The manuscript is organised as follows: Sect. 2 describes the models and experiment protocols for MH; Sect. 3 shows the results of PMIP3 model simulations for the PI and MH experiments and compares with the observations, proxy reconstruction and PMIP2 results; Sect. 4 discusses the inter-model differences in changes of monsoonal precipitation over eastern China and the main findings are concluded in Sect. 5.

\section{Models and experiments}

Within the framework of PMIP3, the mid-Holocene experiment is set up to examine the coupled model's sensitivity to the changes of insolation. The insolation pattern is standardised following Berger (1978), with an eccentricity of 0.018682 , an obliquity of $24.105^{\circ}$ and a longitude of perihelion of $0.87^{\circ}$. The greenhouse gases concentrations are set to the same as that in the pre-Industrial (PI) experiment, except that the $\mathrm{CH}_{4}$ concentration reduces from 760 to $650 \mathrm{ppb}$. Other boundary conditions, such as the aerosols, solar constant, vegetation, ice sheets, topography and coastlines are prescribed as the same as in the PI experiments.

Ten coupled GCMs from the PMIP3 database are accessed in this study and fourteen AOGCMs from the PMIP2 database are used for the comparisons (Table 1). The climatology is derived from the last $100 \mathrm{yr}$ output for each model. Because the number of simulations is small and the model simulations are not symmetrically distributed around the ensemble mean, the model median are considered when evaluating the PMIP3 models simulations. With this solution, outliers have less weight in the analysis. Since the PMIP3 models have different resolutions, a bilinear interpolation was firstly applied to interpolate different climate variables onto the common $1^{\circ} \times 1^{\circ}$ grid. At each grid point and for each variable, the values of model simulations were then sorted from minimum to maximum in order to extract the median value. Since a different model may be chosen as the median at each grid point, there is no inherent direct physical linkage between different fields; they only provide orders of magnitude and the large-scale patterns showing how well the PMIP3 model ensemble captures the climatology over East Asia. Individual model simulations for the TAS and monsoonal precipitation at PI (Figs. S1 and S2) and their changes at MH (Figs. S3 and S4) are included in Supplement. To evaluate the PI simulations of PMIP3 models, the climatology from the CPC (NOAA Climate Prediction Centre) Merged Analysis of Precipitation (CMAP, Xie and Arkin, 1997) and the Climatic Research Unit (CRU, Mitchell and Jones, 2005) data are used for the precipitation and land near-surface temperature, respectively. The National Centre for Environmental Prediction (NCEP, Kalnay et al., 1996) data are used for the comparison of the monsoon circulations.

\section{PMIP3 model results}

\subsection{PI simulations}

Figure 1a and c show the annual mean TAS and summer precipitation (JJA averaged) of present climate observations, respectively. Overall, the PMIP3 model median simulates the similar large-scale patterns of annual mean TAS and the summer monsoonal precipitation as those in the observations (Fig. $1 \mathrm{~b}$ and d). The gradually decreasing of monsoonal 
Table 1. List of the models names, resolutions and references for the PMIP3 and PMIP2 models. Model names expansions are as follows: Beijing Climate Centre Climate System Model (BCC-CSM); Community Climate System Model (CCSM); Commonwealth Scientific and Industrial Research Organisation Mark version 3 (CSIRO Mk3); Max Planck Institute Ocean Model (MPI-OM); Lund-Potsdam-Jena (LPJ) dynamic global vegetation model; Flexible Global Ocean-Atmosphere-Land System Model (FGOALS); First Institute of Oceanography Earth System Model (FIO-ESM); Fast Ocean Atmosphere Model (FOAM); Goddard Institute for Space Studies Model E (GISSmodelE); L'Institut Pierre-Simon Laplace Coupled Model (IPSL-CM); Meteorological Research Institute Coupled General Circulation Model (MRICGCM); and the Met Office model run at Bristol University (UBRIS); and third climate configuration of the Met Office Unified Model (HadCM3).

\begin{tabular}{|c|c|c|c|c|}
\hline & \multirow[b]{2}{*}{ Models } & \multicolumn{2}{|c|}{ Resolution } & \multirow[b]{2}{*}{ References } \\
\hline & & $\begin{array}{l}\text { Atmos. } \\
\text { Lat. } \times \text { Long. }\end{array}$ & $\begin{array}{l}\text { Ocean } \\
\text { Lat. } \times \text { Long. }\end{array}$ & \\
\hline \multirow[t]{10}{*}{ PMIP3 models } & BCC-CSM-1 & T42L26 & $360 \times 232 \mathrm{~L} 40$ & $\mathrm{Wu}(2012)$ \\
\hline & CCSM4 & $0.9^{\circ} \times 1.25^{\circ} \mathrm{L} 26$ & $320 \times 384 \mathrm{~L} 60$ & Gent et al. (2011) \\
\hline & CNRM-CM5 & T127L31 & $362 \times 292$ L42 & Voldoire et al. (2012) \\
\hline & CSIRO-Mk3-6-0 & T63L18 & $192 \times 192$ L31 & Collier et al. (2011) \\
\hline & FGOALS_g2 & $2.81^{\circ} \times 2.81^{\circ} \mathrm{L} 26$ & $360 \times 196$ L30 & Li et al. (2013) \\
\hline & FGOALS_s2 & T42L26 & $360 \times 196$ L30 & Bao et al. (2013) \\
\hline & FIO-ESM & T42L26 & $384 \times 320 \mathrm{~L} 40$ & Song et al. (2012) \\
\hline & IPSL-CM5A-LR & $1.875^{\circ} \times 3.75^{\circ} \mathrm{L} 39$ & $182 \times 149 \mathrm{~L} 31$ & Dufresne et al. (2012) \\
\hline & MPI-ESM-P & T63L47 & $256 \times 220 \mathrm{~L} 40$ & Giorgetta et al. (2012) \\
\hline & MRI-CGCM3 & TL159L48 & $364 \times 368$ L5 1 & Yukimoto et al. (2012) \\
\hline \multirow[t]{14}{*}{ PMIP2 models } & CCSM3 & T42L18 & $1^{\circ} \times 1^{\circ} \mathrm{L} 40$ & Otto-Bliesner et al. (2006) \\
\hline & CSIRO-Mk3L-1.0 & R21L18 & $3.18^{\circ} \times 5.625^{\circ} \mathrm{L} 21$ & Phipps (2006) \\
\hline & CSIRO-Mk3L-1.1 & R21L18 & $1.59^{\circ} \times 2.81^{\circ} \mathrm{L} 21$ & Phipps (2006) \\
\hline & ECBILTCLIOVECODE & $\mathrm{T} 21 \mathrm{~L} 3$ & $3^{\circ} \times 3^{\circ} \mathrm{L} 20$ & Renssen et al. (2005) \\
\hline & ECHAM5-MPI-OM1 & T63L31 & $1.5^{\circ} \times 1.5^{\circ} \mathrm{L} 40$ & Jungclaus et al. (2006) \\
\hline & ECHAM5-MPI-OM127-LPJ & T63L31 & $1.5^{\circ} \times 1.5^{\circ} \mathrm{L} 40$ & Marsland et al. (2003) \\
\hline & FGOALS-1.0g & $2.81^{\circ} \times 2.81^{\circ} \mathrm{L} 26$ & $1^{\circ} \times 1^{\circ} \mathrm{L} 30$ & Yu et al. (2004) \\
\hline & FOAM & R15L18 & $128 \times 128 \mathrm{~L} 24$ & Jacob et al. (2001) \\
\hline & GISSmodelE & $4^{\circ} \times 5^{\circ} \mathrm{L} 12$ & $4^{\circ} \times 5^{\circ} \mathrm{L} 18$ & Schmidt et al. (2006) \\
\hline & IPSL-CM4 & $2.5^{\circ} \times 3.75^{\circ} \mathrm{L} 19$ & $0.5^{\circ} \times 2^{\circ} \mathrm{L} 31$ & Marti et al. (2010) \\
\hline & MIROC3.2 & T42L20 & $0.5^{\circ} \times 1.4^{\circ} \mathrm{L} 43$ & K-1 Model Developers (2004) \\
\hline & MRI-CGCM2.3.4fa & $\mathrm{T} 42 \mathrm{~L} 30$ & $0.5^{\circ} \times 2.5^{\circ} \mathrm{L} 23$ & Yukimoto et al. (2006) \\
\hline & MRI-CGCM2.3.4nfa & T42L30 & $0.5^{\circ} \times 2.5^{\circ} \mathrm{L} 23$ & Yukimoto et al. (2006) \\
\hline & UBRIS-HadCM3M2 & $2.5^{\circ} \times 3.75^{\circ} \mathrm{L} 19$ & $1.25^{\circ} \times 1.25^{\circ} \mathrm{L} 23$ & Gordon et al. (2000) \\
\hline
\end{tabular}

rainfall from the tropics towards high latitudes and the northwest part of China is captured. For the EASM, a dominant feature of the rainbelt extending from the middle and lower reaches of the Yangzi River to the east of Japan, also known as Meiyu in China and Baiu in Japan, is also broadly reproduced by the model median, but with a weaker precipitation (Fig. 1d). However, several differences can be identified between the model median and the observations. The TAS is cooler in the model median over most parts of East Asia and the western Pacific, with the maxima over the Tibetan Plateau and the Northeast Asia (Fig. 1b). Note that the greenhouse gases concentrations are lower in the PI simulations than present climate, which could explain about 0.6$1.4^{\circ} \mathrm{C}$ cooling between model PI results and the observations (Folland et al., 2001; IPCC, 2007), the PMIP3 model median still exists a cold bias of annual mean TAS over most area of the East Asia (Fig. 1b). The precipitation is underestimated by PMIP3 model median in the Bay of Bengal, the western
Pacific and the regions of Meiyu rainbelt, while the rainfall over Tibetan Plateau and the northern China is larger than the observed that contributes to the cooling of annual mean TAS in above regions (Fig. 1d).

Although the model medians are quite similar to the observations for the patterns of TAS and summer precipitation, the individual PMIP3 model shows different behaviours in the PI simulations. The contours in Fig. $1 b$ and $d$ that indicate the standard deviation for the annual mean TAS and summer monsoon precipitation, respectively, further demonstrate the large inter-model differences. The model spread for TAS is large over the Tibetan Plateau that leads to different meridional thermal contrasts to its south between PMIP3 models. The TAS gradient over Eastern China $\left(100-120^{\circ} \mathrm{E}\right.$, $20-50^{\circ} \mathrm{N}$ ) also differs from one model to the other (Fig. 1b) which may imply different influences between models on the climate of the lower reaches of Yangzi River. The largest spread of precipitation is located in the tropical regions and to 

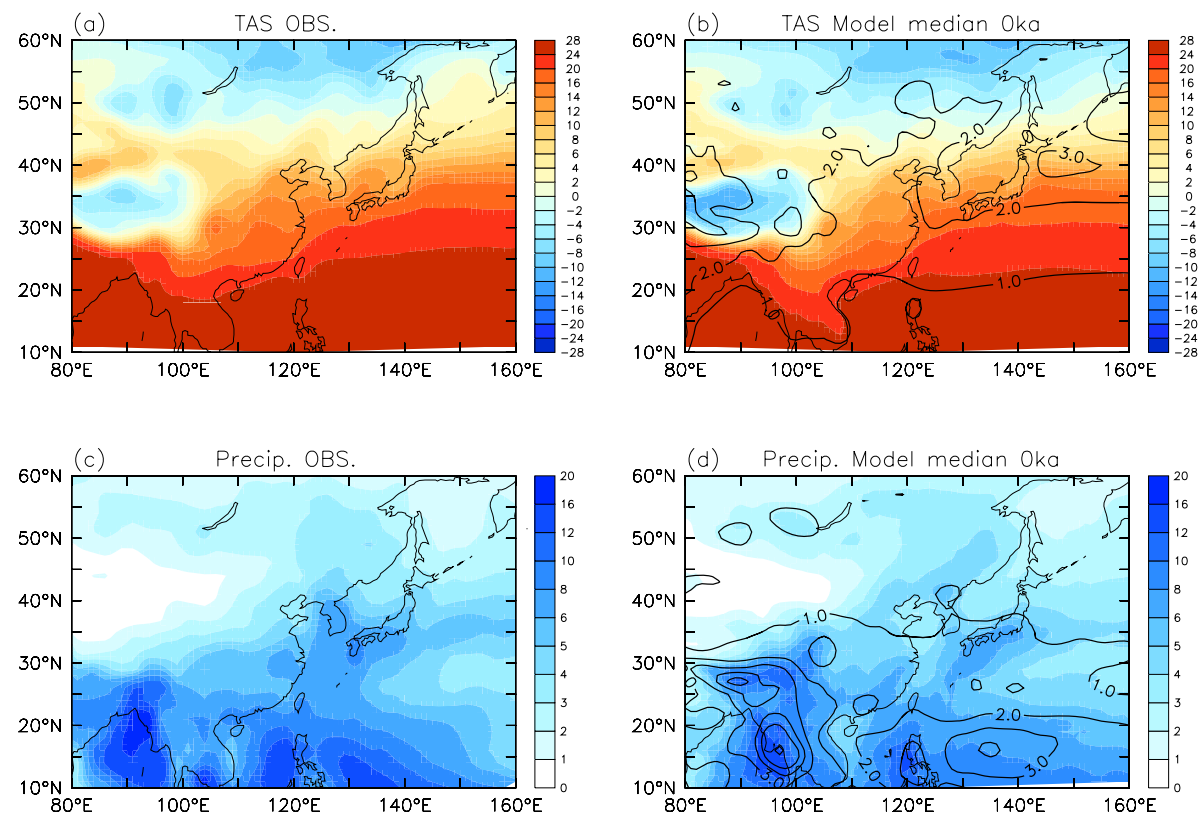

Fig. 1. (a) Observed annual mean surface air temperature (TAS, ${ }^{\circ} \mathrm{C}$ ) merged from CRU data on land and NCEP reanalysis over the ocean; (b) same as (a) but for the PMIP3 model median; (c) observed summer precipitation (JJA, mm $\mathrm{d}^{-1}$ ) from CMAP data; and (d) same as (c) but for the PMIP3 model median. The contours in (b) and (d) denote the standard deviation of the 10 PMIP3 models for the TAS and precipitation, respectively.

the south of Tibetan Plateau, particularly in the Bay of Bengal and the western Pacific (Fig. 1d), which are associated with the different thermal contrasts as simulated by individual PMIP3 model.

The large-scale circulation of EASM in PMIP3 model median broadly resembles that in the NCEP reanalysis. The southerly components from the Indian Ocean and the western Pacific bring the water vapour to East Asia, and the subtropical high controls the Northwest Pacific of which its ridge tends to play an important role in determining the position of monsoonal rainbelt (Fig. 2a and b). The differences of monsoonal circulation between PMIP3 model median and the observations explain the bias of precipitation in the PI simulations (Fig. 1d), for example the weaker than observed updraft at 500 hpa located over the Bay of Bengal and southeast China leads to weaker monsoonal rainfall, while the stronger updraft corresponds to the excessive precipitation over the southern part of the Tibetan Plateau in the model median. In the Northwest Pacific, the simulated weaker precipitation can also be attributed to the anomalous anticyclonic circulation (Fig. 2b) related to the cooler sea surface temperature (SST) simulated in the warm pool region and the tropics (Fig. 1b).

The seasonal cycle of monsoonal rainfall over Eastern China is presented in Fig. 2c for the CMAP data, which indicates the seasonal movement of the EASM rainbelt. The stepwise meridional displacement of the rainbelt is one of the most distinctive features of EASM compared with other tropical monsoon systems (Tao and Chen, 1987), with the features that the main rainbelt persists in southern China around $25^{\circ} \mathrm{N}$ before mid-May, which is also known as the East Asian Spring Persist Rainfall (Wu et al., 2007), and then it moves to the lower-middle reaches of the Yangzi River $\left(\sim 30^{\circ} \mathrm{N}\right)$ in June and forms the Meiyu rainbelt. In July and August, the monsoon precipitation expands further north to northern China $\left(\sim 40^{\circ} \mathrm{N}\right)$ and gradually retreats towards the equator afterward (Fig. 2c). The PMIP3 model median broadly reproduces the seasonal cycle of EASM rainbelt as that in the CMAP data (Fig. 2d), however, the displacement from southern China to the lower-middle reaches of Yangzi River is not well represented by the PMIP3 model median, which corresponds to the weaker than observed precipitation of the Meiyu rainbelt as shown in Fig. 1d.

\subsection{Changes at MH}

Due to the change of the Earth's orbital parameters in midHolocene, the Northern Hemisphere receives more insolation during boreal summer that leads to a significant warming over the Eurasia continent beyond $30^{\circ} \mathrm{N}$ (Fig. 3a). The TAS shows a cooling in lower latitudes and over the ocean, thus, the land-sea thermal contrast is increased by $6 \mathrm{ka}$ favouring the enhancement of the EASM circulations. The changes of TAS during boreal winter show a cooling over most regions of Eurasia continent (Fig. 3b) that are associated with the decreased insolation in the NH. Such changes implies that the solar radiation is one of the most important factors that dominating the changes of TAS in climate models. Concerning the changes of annual mean TAS, PMIP3 model median shows 

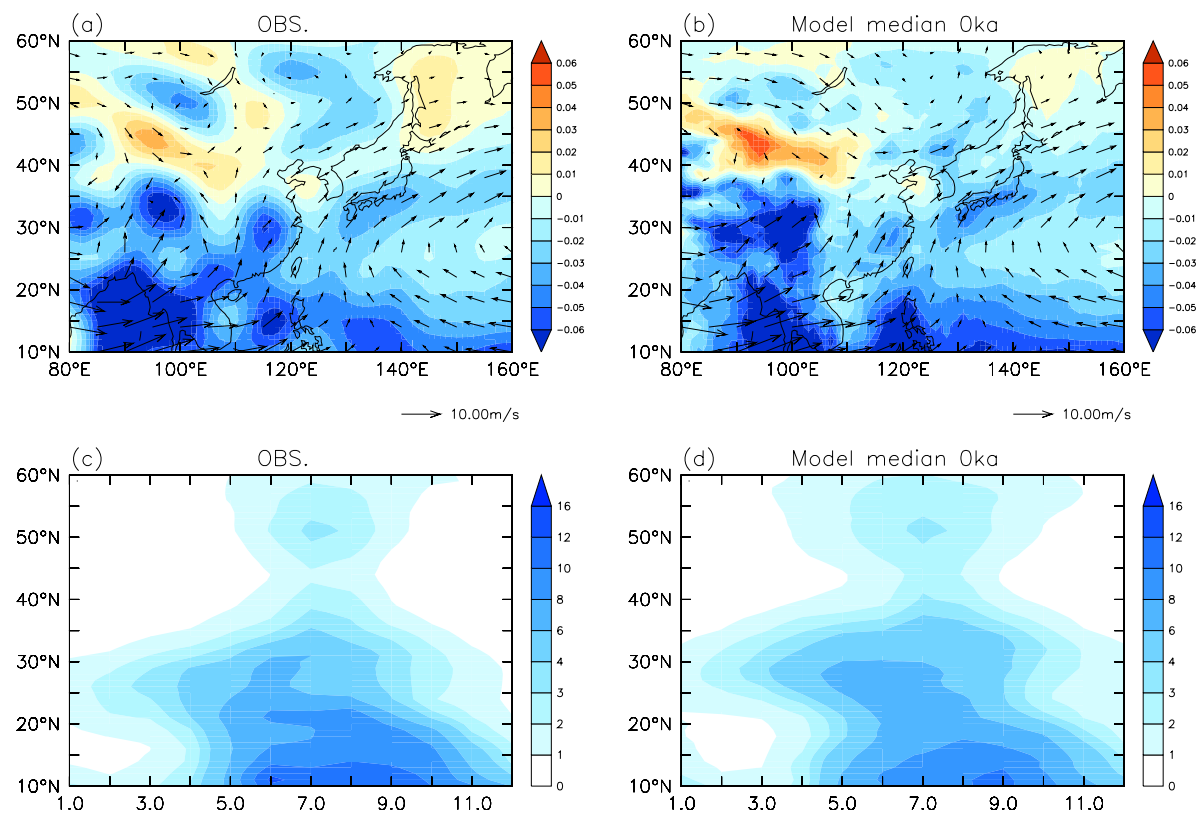

Fig. 2. (a) EASM monsoonal circulation in NCEP; (b) same as (a) but for the PMIP3 model median; (c) seasonal cycle of the EASM precipitation over eastern China $\left(100-120^{\circ} \mathrm{E}\right.$ averaged $)\left(\mathrm{mm} \mathrm{d}^{-1}\right)$; (d) same as (a) but for the PMIP3 model median. Vectors are for the wind filed at $850 \mathrm{hpa}\left(\mathrm{m} \mathrm{s}^{-1}\right)$ and the vertical velocity at $500 \mathrm{hpa}(\mathrm{d} p / \mathrm{d} t)$ are shown as shaded in (a) and (b).
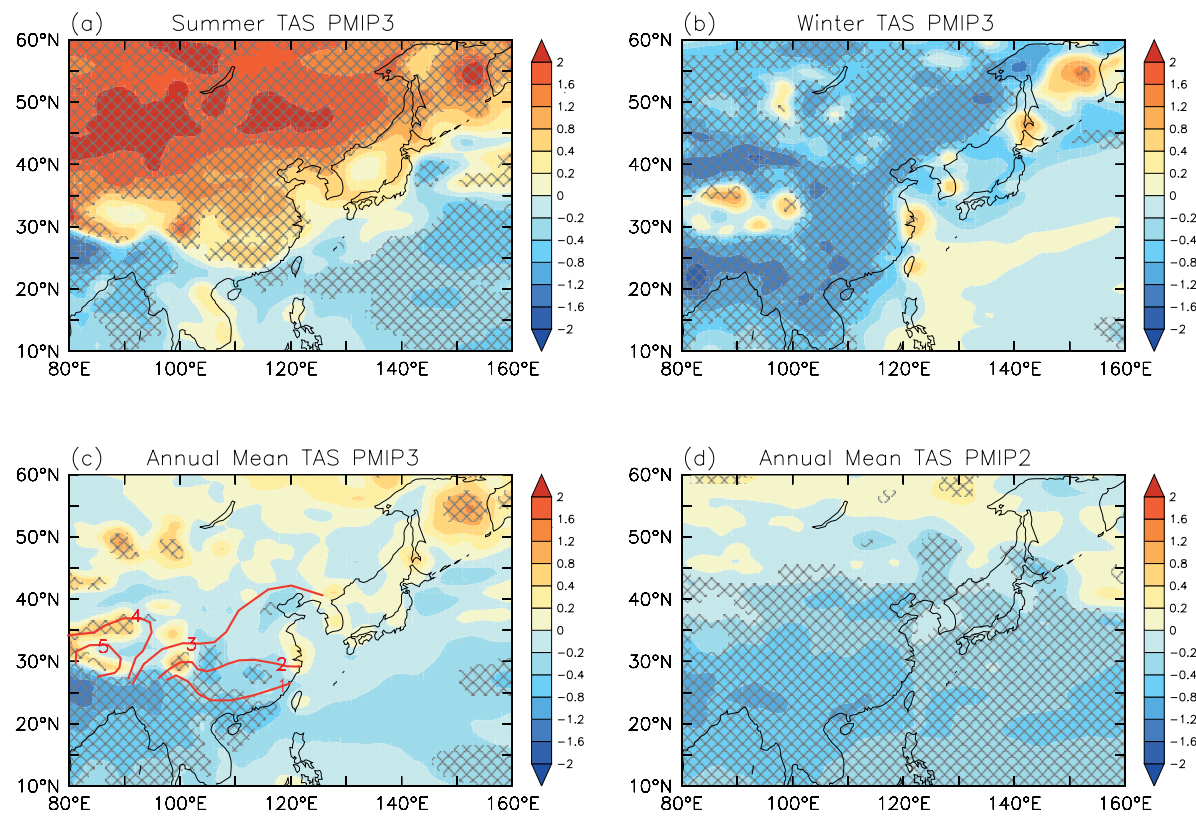

Fig. 3. The changes of TAS at MH for PMIP3 model median (a) summer (JJA averaged); (b) winter time (DJF); (c) annual mean and (d) the changes of annual mean TAS for PMIP2 model median. Unit: ${ }^{\circ} \mathrm{C}$. The shadow indicates areas where the model median exceeds 1.2 times of the inter-model standard deviation $(1.2 \sigma)$, which indicates the significance of the changes. The red contours in Fig. $3 \mathrm{c}$ are from Shi et al. (1993), which indicate the proxy estimates of the changes of annual mean TAS at MH compared to present climate.

an overall slightly warming in the northern part of East Asia (Fig. 3c), which is similar to the results from PMIP2 models (Fig. 3d), yet these changes are not significant. Previous studies of proxy data (Shi et al., 1993) estimated a $1-3{ }^{\circ} \mathrm{C}$ warming of annual mean TAS over Eastern China and the warming reaches $4-5^{\circ} \mathrm{C}$ over the Tibetan Plateau (red contours in Fig. 3c). However, PMIP3 model median fails to simulate the warming in Eastern China, but of a $0.2-0.4^{\circ} \mathrm{C}$ cooling, which is similar to the PMIP2 results. One of the differences between PMIP3 and PMIP2 models is that the PMIP3 

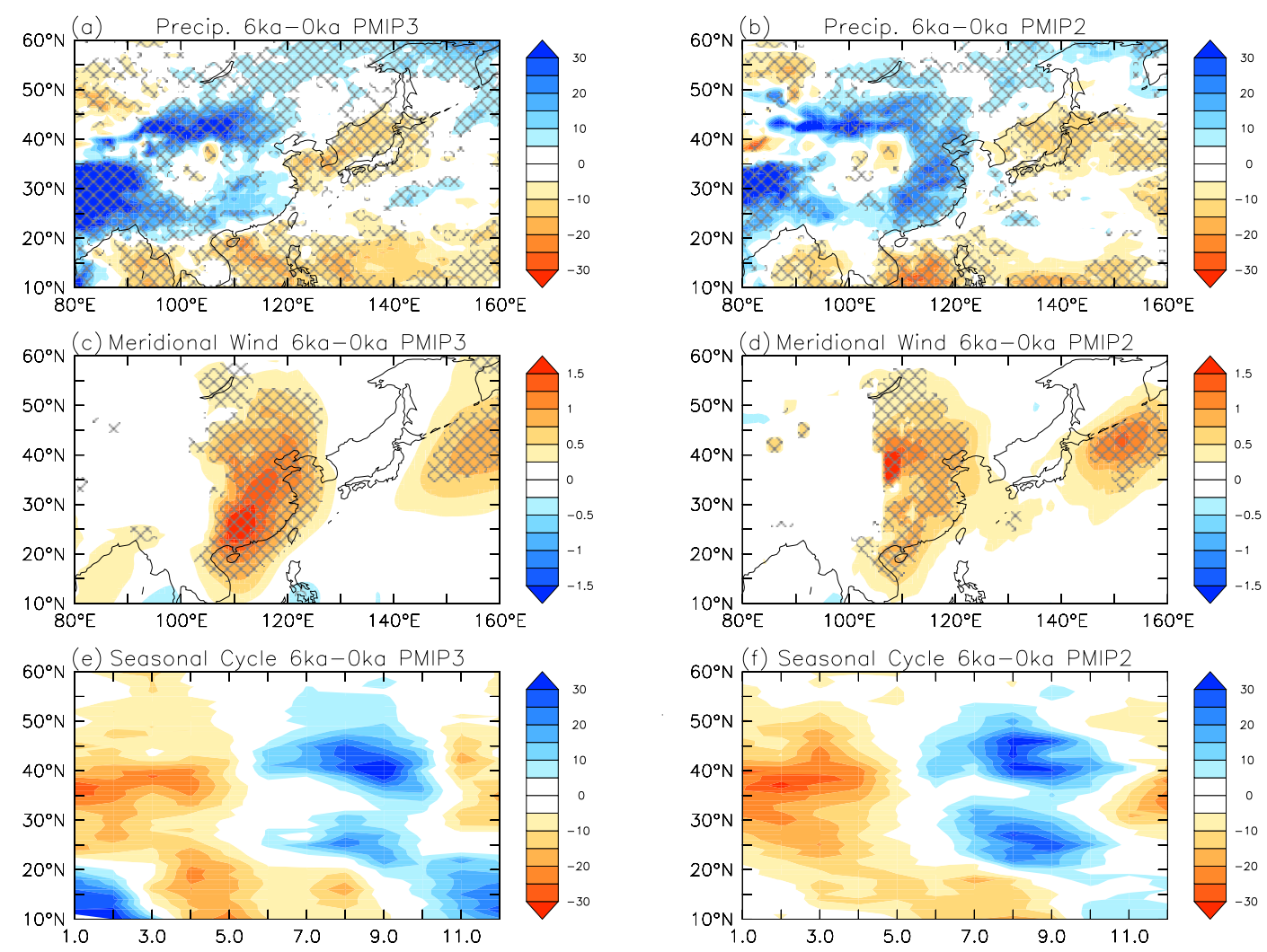

Fig. 4. Changes of EASM characteristics for the PMIP3 model median (left column) and the PMIP2 model median (right). (a) and (b) the summer precipitation (in \%); (c) and (d) the meridional wind at $850 \mathrm{hpa}$ of JJA (positive northward, $\mathrm{m} \mathrm{s}^{-1}$ ); (e) and (f) the seasonal cycle of monsoonal precipitation (in \%). The shadow indicates areas where the model median exceeds 1.2 times of the inter-model standard deviation $(1.2 \sigma)$, which indicates the significance of the changes.

model median simulates a warming of sub-regional scales over the Tibetan Plateau that is not shown in the PMIP2 model median, though the warming is much smaller than that estimated by proxy data. In the northern part of East Asia, the PMIP3 model median also shows a relatively stronger warming than PMIP2 results (Fig. $3 \mathrm{c}$ and d). Note that the changes of TAS are not significant over the entire region of the Tibetan Plateau (Fig. 3a-c), which implies the large intermodel differences among PMIP3 models, it may have different influences on the climate of Eastern China located in its downstream areas.

Both of the PMIP2 and PMIP3 model medians show an enhanced summer precipitation of EASM over most regions of Eurasia continent (Fig. 4a and b). The summer precipitation increases by $6.57 \%$ over the whole of Eastern China at MH for PMIP3 models, which is slightly weaker than the PMIP2 result $(8.79 \%)$. The proxy data suggested an overall enhanced annual precipitation over China at $\mathrm{MH}$ as summarised in Wang et al. (2010). Since about $40-60 \%$ of annual precipitation results from the summer precipitation over most parts of China (Fu et al., 1992), it is suitable to evaluate the PMIP3 model median with the proxy data. The enhanced precipitation in northern China and the southern parts of Tibetan Plateau is significant and broadly agrees with the proxy reconstructions, e.g., previous studies (Shi and Song, 2003; Sun et al., 2006) suggested about 20-50\% higher annual precipitation over Daihai Lake $\left(112.6^{\circ} \mathrm{E}, 40.5^{\circ} \mathrm{N}\right)$ and Diaojiao Lake $\left(112.4^{\circ} \mathrm{E}, 41.3^{\circ} \mathrm{N}\right)$ in northern China, the PMIP3 model median reproduced an increase of $30 \%$ over this region that agrees with the range of precipitation changes at $\mathrm{MH}$; the precipitation increased about $30 \%$ in the southern part of the Tibetan Plateau as simulated by PMIP3 model median that was also similar to the proxy records from Ren Co Lake $\left(96.7^{\circ} \mathrm{E}, 30.7^{\circ} \mathrm{N}\right.$ ) (Tang et al., 2000). The changes in precipitation over southern China are not significant (Fig. 4a) due to the large inter-model differences among PMIP3 models. However, it is hard to conclude the model results in these regions because of the lacking and uncertainties of the proxy data.

During mid-Holocene, the EASM monsoonal circulations are strengthened due to the enhanced land-sea thermal contrast during boreal summer (Fig. 3a). The southerly winds are stronger than that in the PI simulations of PMIP3 models and they prevail over most regions of Eastern China (Fig. 4c), which is similar to the changes of PMIP2 models (Fig. 4d). The stronger southerly winds favour the water 

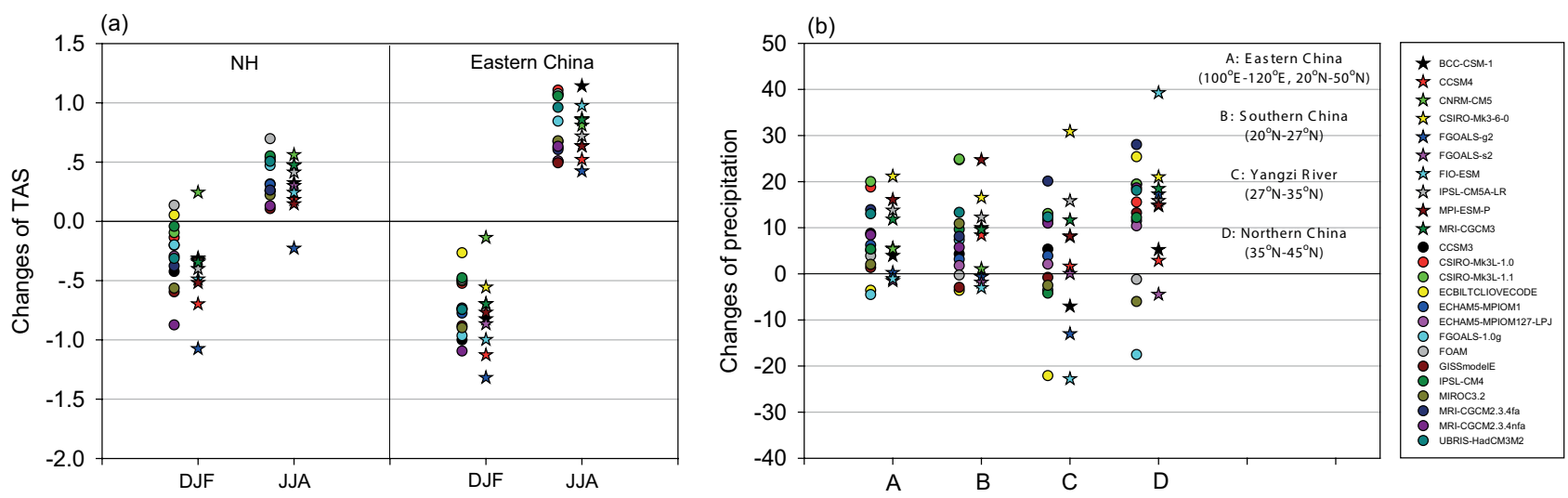

Fig. 5. (a) Changes of surface air temperature (TAS, $\left.{ }^{\circ} \mathrm{C}\right)$ in the Northern Hemisphere $(\mathrm{NH})$ and Eastern $\mathrm{China}\left(100-120^{\circ} \mathrm{E}, 20-50^{\circ} \mathrm{N}\right)$ at $6 \mathrm{ka}$ for boreal winter (December-February, DJF) and summer (June-August, JJA); (b) changes of the summer monsoonal precipitation in Eastern China and its three sub-domains broadly divided by latitudes - Southern China $\left(20-27^{\circ} \mathrm{N}\right)$, mid-lower reaches of Yangzi River $\left(27-35^{\circ} \mathrm{N}\right)$ and Northern China $\left(35-45^{\circ} \mathrm{N}\right)$. Star symbols indicate the results from PMIP3 models and the circles are for PMIP2 results. Different colours are used to distinguish the models within PMIP3 and PMIP2 simulations.

vapour transport from the low latitudes to mid-high latitudes that contribute to the enhancement of EASM summer precipitation. However, the changes of summer precipitation are not significant over the southern China and the mid-lower reaches of Yangzi River (Fig. 4a) which differs from the PMIP2 models, implying that EASM intensity is better characterised by the monsoonal winds rather than the local rainfall over southern China.

The seasonal cycle of EASM is also being modified in response to the changes of insolation at $6 \mathrm{ka}$ that the precipitation decreases before mid-May during the phase of East Asian Spring Persist Rainfall and then it strengthens when the monsoonal rainbelt jumps to the lower-middle reaches of Yangzi River and northern China (Fig. 4e). Meanwhile, the retreat of EASM is also delayed by about one month because the enhancement of precipitation persists until the end of September. Such changes are similar to that of PMIP2 models, as shown in Fig. 4f.

\subsection{Model spread}

Although the PMIP3 model median captures the large-scale characteristics of the EASM, the inter-model differences are large and the regional features differ from one model to the other. As for the PI simulations, the model spreads are large over the Tibetan plateau for the TAS and in the tropics and to the south of the Tibetan Plateau for the precipitation, respectively (Fig. 1b and d). These are also the regions where the PMIP3 model median shows a larger deviation from the observations. During the mid-Holocene, the changes of TAS are significant over most regions of the Eurasia continent during the boreal summer and winter except over the Tibetan Plateau, showing the dominant role of the incoming solar radiation in all the models (Fig. 3a and b). However, the changes of annual mean TAS are relatively small and less significant in PMIP3 models (Fig. 3c), which can be attributed to the large inter-model differences in response to the insolation forcings. The changes of EASM at MH are featured by increased precipitation and enhanced monsoonal circulation over the monsoon regions, however, the changes for the precipitation are only significant over the Tibetan Plateau and northern China for the PMIP3 models. In the regions of southern China and along the Yangzi River, the strengthening of southerly winds better represents the changes of EASM.

To better show the model spread, we plot in Fig. 5a the changes of TAS in the Northern Hemisphere and the Eastern China and in Fig. 5b for the changes of summer precipitation over Eastern China and its three sub-domains broadly divided by latitudes (Southern China: $20-27^{\circ} \mathrm{N}$; Northern China: $35-45^{\circ} \mathrm{N}$; Yangzi River reaches: $28-35^{\circ} \mathrm{N}$ ) for each PMIP3 model. Overall, the changes of TAS follow the changes of insolation that increase during boreal summer and decrease in winter. The PMIP3 models are relatively closer from one to the other in the NH when compared with the PMIP2 models, except for some outliers (Fig. 5a). The changes of TAS in Eastern China are also dominated by the changes of insolation at $\mathrm{MH}$. Both the sign and magnitude of the changes of TAS are similar between PMIP3 and PMIP2 models (Fig. 5a). None of the PMIP3 model reproduces the winter warming in Eastern China as suggested by proxy data studies. The model-data mismatch still exits in PMIP3 models as that in PMIP2 models (Jiang et al., 2012).

The changes of summer precipitation over Eastern China are shown in Fig. 5b by changes in percentage. The PMIP3 models show no significant changes of the model spread when compared with PMIP2 models. The regional precipitation is featured by an enlarged spread over the lower reaches of Yangzi River. Six models, except for BCC-CSM-1, two FGOALSs and FIO-ESM, simulate consistent increases of 
precipitation from the south to north in Eastern China, but with different locations of the maximum precipitation changes, e.g., the CCSM4 shows a large increase of precipitation in Southern China, but relatively smaller changes over Northern China and the Yangzi River reaches while CSIROMk3-6-0 simulates a large increase of summer precipitation over the Yangzi River reaches (Fig. 5b). Other four models simulate relatively complex patterns of the precipitation changes. The BCC-CSM-1 simulates a three core pattern where the precipitation reverses signs between the Yangzi River reaches and Northern and Southern China, while the FGOALS-g2 and FIO-ESM show an increased rainfall in Northern China, but less in the south that are related to the changes in monsoon circulation. The change of precipitation in FGOALS-s2 reduces slightly in both Northern and Southern China and remains almost unchanged along the Yangzi River.

\section{Discussion}

Generally, the magnitude of EASM precipitation depends on the large-scale circulation and the atmospheric water vapour content. As shown by the PMIP3 model median, the pattern of precipitation (Fig. 1d) is closely associated with the vertical velocity at $500 \mathrm{hpa}(\omega 500)$ (Fig. 2b). However, the model's behaviour differs from one to the other which are partially related to the different convective schemes in the model. The model sensitivity to the changes of insolation at $\mathrm{MH}$ is also different among models, for example, the changes of water vapour content are related to large-scale circulation and the local hydrology. To better demonstrate the model spread in Eastern China for the change of precipitation, we plotted the changes of $\omega 500$ and the water vapour content in Figs. 6 and 7, respectively, from which the changes of EASM precipitation in Eastern China can be qualitatively derived from the configuration of the changes of $\omega 500$ and water vapour content. Four models (CNRM-CM5, CSIROMk3-6-0, MPI-ESM-P and MRI-CGCM3) show a strengthening of the $\omega 500$ over the most parts of Eastern China (Fig. 6) while the water vapour content increases dramatically in this region (Fig. 7), this explains why they simulate stronger monsoonal precipitation in all three sub-domains of Eastern China (Fig. 5b). Regional features can also be identified from the changes of $\omega 500$, e.g., the CSIRO show a maximal change of $\omega 500$ over the lower reaches of Yangzi River (Fig. 6, CSIRO) that favour a larger change of precipitation in this region when compared with Northern and Southern China (Fig. 5b). CCSM4 simulates a similar change of $\omega 500$ over Eastern China, but slightly decreased water vapour content in Southern China (Figs. 6 and 7, CCSM4), however, the changes of precipitation are larger in Southern China than the changes in Northern China and the lower reaches of Yangzi River (Fig. 5b). This implies that the change of large-scale circulation tends to determine the sign of changes in precipitation while the changes in water vapour content would influence the magnitude of precipitation changes. This relationship also applies to the other four models (BCCCSM-1, two FGOALSs and FIO-ESM) of which the changes of precipitation show a more complex pattern. The changes of $\omega 500$ in BCC-CSM-1 show a similar three cores pattern that corresponds to the increased rainfall in Northern and Southern China and less precipitation along the Yangzi River reaches. For the FGOALS-g2, the $\omega 500$ weakens over Southern China and the Yangzi River reaches and strengthens over Northern China, while the water vapour content increases in Northern China and decreases to the south, such configuration explains the changes of monsoonal precipitation of FGOALS-g2 as shown in Fig. 5b. Although this relationship applies for most of the PMIP3 models, the relative importance of the changes of $\omega 500$ and the water vapour content are model dependent that needs further quantitatively analysis. The impact of large-scale circulation and local hydrology on the changes of water vapour content also needs further studies.

The climate condition of the Tibetan Plateau is one of the important factors that influence the activity of EASM (Ding and Chan, 2005). Studies of Wu et al. (2007) suggest that during the summer time, the meridional winds and vertical motions forced by the Eurasian continental-scale heating and the Tibetan Plateau local heating are in phase over the eastern and central parts of the continent, therefore, the monsoon in East Asia intensified. The large inter-model differences of the TAS over the Tibetan Plateau for PI simulations (Fig. 1b) and the changes at mid-Holocene (Fig. 3c) may contribute to the model spread in simulating the climate of eastern China. Numerical experiments with atmospheric GCMs (AGCMs) show that atmospheric heating induced by the rising temperatures over the Tibetan Plateau can enhance East Asian subtropical frontal rainfall (Wang et al., 2008). This mechanism may be applied to explain the large model spread of the precipitation in the lower reaches of Yangzi River. Therefore, we plot in Fig. 8 the changes of monsoonal precipitation over the lower reaches of Yangzi River as a function of the changes of TAS over Tibetan Plateau. The change of simulated TAS over Tibetan Plateau show a large spread ranging from -0.7 to $+0.3^{\circ} \mathrm{C}$, which may be related to the different simulations of the snow cover over the Tibetan Plateau. Six models show a positive relationship for the change between the precipitation and TAS over TP, but the sensitivity is model dependent (Fig. 8). The changes of precipitation in the three models of IPSL-CM5A-LR, MPIESM-P and MRI-CGCM3 are more sensitive to the changes of large-scale circulation and water vapour content so that the mechanism from the AGCMs does not apply to these simulations. Since the mechanism of the linkage is found to be through two distinct Rossby wave trains and the isentropic uplift to the east of the Tibetan Plateau, which deform the western Pacific Subtropical High and enhance moisture convergence toward the East Asia subtropical front (Wang et al., 

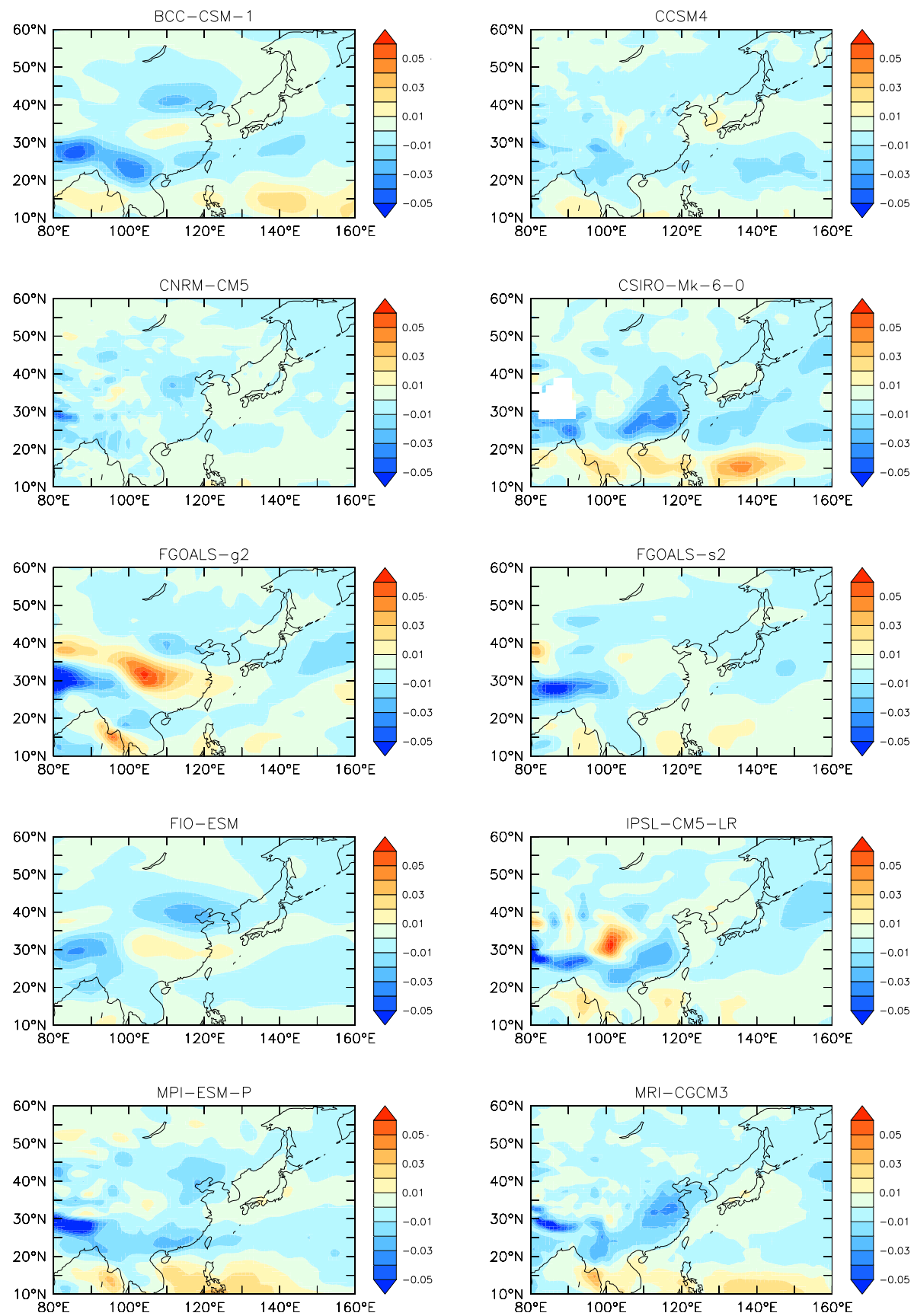

Fig. 6. The changes of the vertical velocity at mid-Holocene for the PMIP3 model in this study. Units: $\mathrm{d} p / \mathrm{d} t$.

2008), the model's abilities in realistically representing the huge steep topography may have great impact on the coupling between the changes over the Tibetan Plateau and the EASM activities.

\section{Conclusions}

Ten coupled models that participated in the PMIP3 are used to investigate their ability in simulating the East Asian Summer Monsoon in the PI simulations and the changes of monsoon circulation and precipitation at mid-Holocene. The model medians are extracted for several variables rather than the model ensemble mean for the analyses. Though with biases when compared to the observations, the PMIP3 model median captures the basic features of the climatology in East 

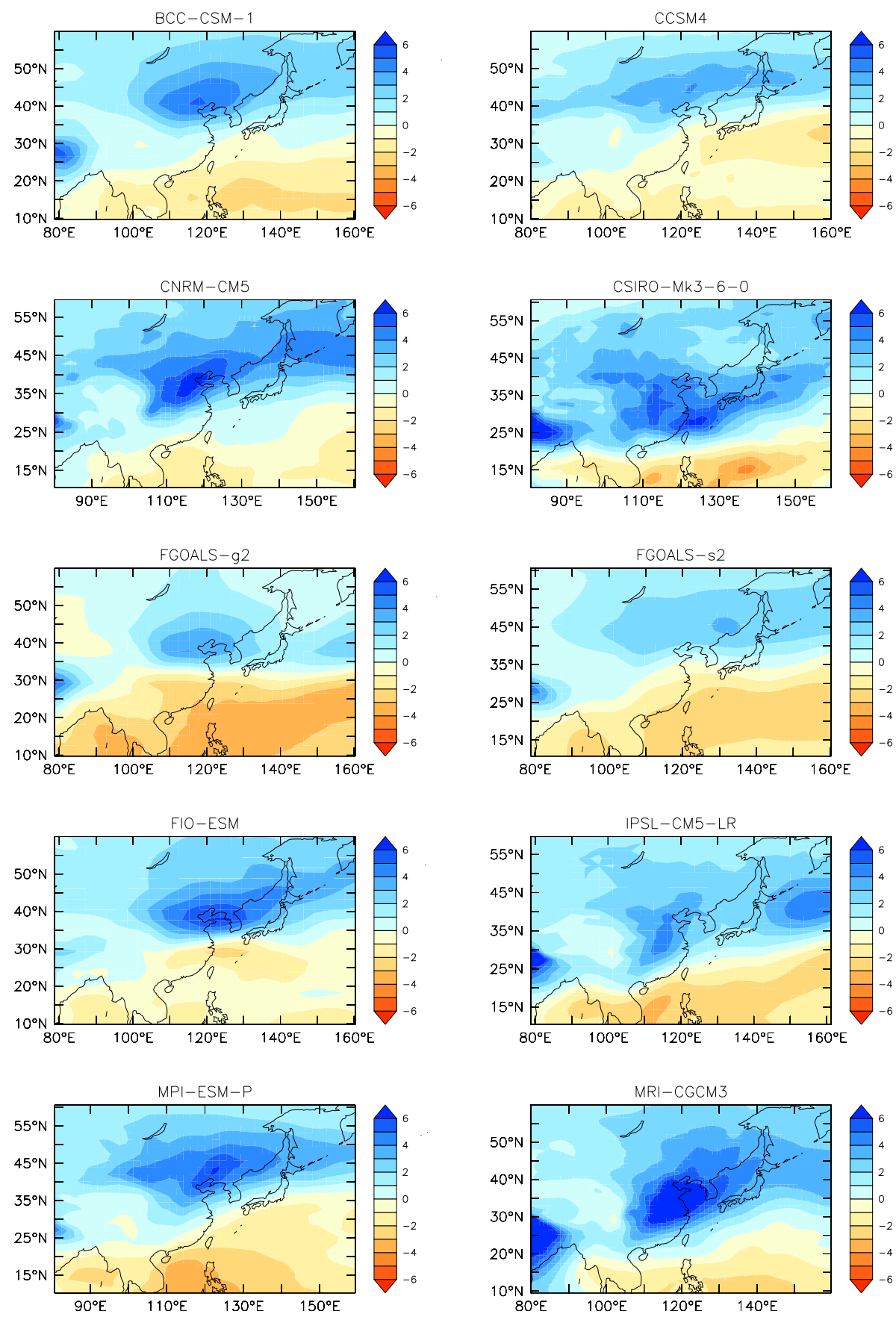

Fig. 7. Same as Fig. 6, but for the changes of water vapour content. Units: $\mathrm{kg} \mathrm{m}^{-2}$.

Asia, such as the land-sea thermal contrast and the gradual decrease of precipitation towards the inland of the Asian Continent (Fig. 1). The atmospheric circulation of the EASM simulated by PMIP3 model median broadly resembles the pattern as that in the NCEP reanalysis (Fig. 2a). However, the vertical velocity at $500 \mathrm{hpa}$ is underestimated by the PMIP3 model median (Fig. 2b) that explains the weaker than observed precipitation at the Bay of Bengal, Eastern China and the western Pacific (Fig. 1d). Two distinct features of EASM, the Meiyu rainbelt and the stepwise meridional displacement of the monsoon rainbelt (Fig. 2d) are reasonably represented by the PMIP3 model median.

At mid-Holocene, the PMIP3 model median shows a warming of TAS over the East Asia continent and cooling over the ocean during the boreal summer (Fig. 3a) and reverses in winter (Fig. 3b), which results from the responses to the change of insolation and the different thermal capacity between land and the ocean. Where the annual mean 


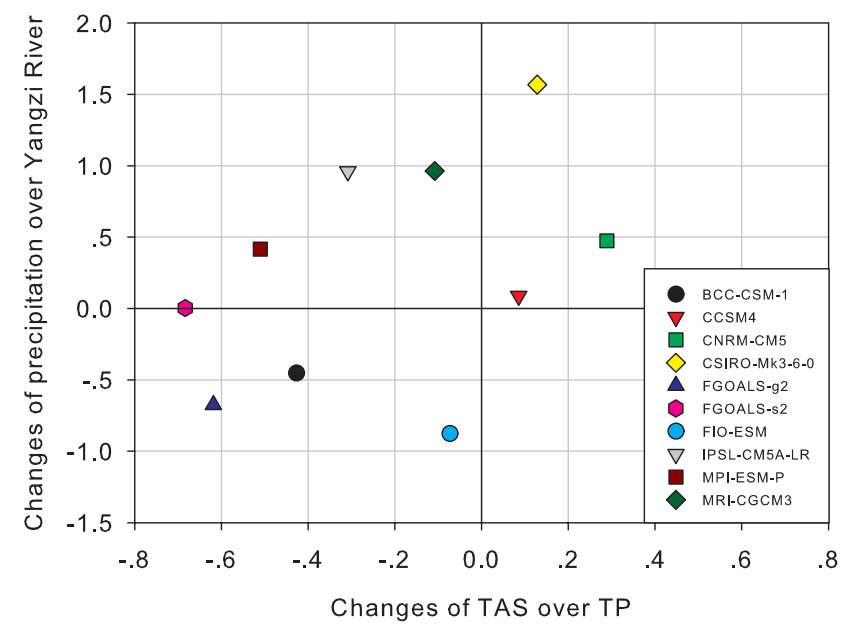

Fig. 8. The changes of precipitation in the lower reaches of Yangzi River (y-axis, $\mathrm{mmd}^{-1}$ ) as a function of the changes of TAS ( $\mathrm{x}$ axis, ${ }^{\circ} \mathrm{C}$ ) over the Tibetan Plateau (TP, $85-95^{\circ}$ E, $\left.25-35^{\circ} \mathrm{N}\right)$ during boreal summer.

TAS is concerned, the PMIP3 model median shows a larger warming in the northern part of East Asia than that in the PMIP2 models, though such changes are not significant. The PMIP3 model median shows an overall warming over the Tibetan Plateau for the annual mean TAS, which is not seen in the PMIP2 models, yet the warming is much weaker than estimated from previous pollen records studies (Shi et al., 1993). The changes of TAS over eastern China show opposite sign to those derived from proxy data at $\mathrm{MH}$, this modeldata mismatch still exists as the results from PMIP2 models (Jiang et al., 2012). The enhanced land-sea contrast during boreal summer favours the strengthening of the EASM circulation, featuring the stronger southerly winds prevailing over the eastern China (Fig. 4c), which in turn favours the northward water vapour transportation (Fig. 6). The spatial patterns for the changes of EASM precipitation are similar between PMIP3 and PMIP2 model medians, with significant change in Northern China and the southern parts of the Tibetan Plateau. The inter-model differences are large among PMIP3 models for the changes in summer precipitation over Southern China, which is a notable difference when compared with the PMIP2 results. The seasonal cycle of the EASM is modified by the change of insolation, in which the precipitation weakens in spring and strengthens during the summertime. The monsoon retreat is also delayed by one month at MH (Fig. 4e). Previous studies show that the thermal maxima in China occurred in 7200-6000 yr BP and the climatology at $\mathrm{MH}$ may not be a good representative for the megathermal in China. In fact the proxy data at MH contain the responses of climate system to the forcings before $6 \mathrm{ka}$ as suggested in Yin and Berger $(2010,2012)$, which used the insolation forcing at $12 \mathrm{ka} \mathrm{BP}$ to simulate the Holocene peak climate by taking into account a few thousand years difference between the forcing and responses in the climate system. Therefore, the forcings specified in PMIP3 experiment protocols for MH may be not the best forcings to simulate the Holocene peak in China and may partly contribute to the discrepancies when comparing the model results with proxy data.

Both in the simulations of PI and MH, the model spreads are large for the TAS and the EASM precipitation, particularly over the Tibetan Plateau. It is hard to conclude any improvements in simulating the TAS at MH for the PMIP3 models when compared to the PMIP2 results, because the model-data mismatch still exists and the range of model spread are similar (Fig. 5a). The model spread becomes larger in simulating the EASM precipitations over the lower reaches of Yangzi River (Fig. 5b). Such changes can be related to the model's different behaviours of simulating the configuration of changes in monsoon circulation and water vapour content (Figs. 6 and 7), of which the changes of largescale circulation determine the sign of changes in precipitation while the changes of water vapour content have an impact on the magnitude of the changes in precipitation. The large model spread for the TAS over Tibetan Plateau tends to play a role in the climate simulation for the eastern China. The positive relationship between the TAS and the subtropical front precipitation that derived from the AGCMs simulations can partially explain the differences among models, but it does not apply for all the PMIP3 simulations (Fig. 8).

The model spread for the changes of EASM at midHolocene can be resulted from both the model bias in the PI simulation and the different sensitivity to the forcings at MH. However, it is hard to discuss their relative roles from existing PMIP3 simulations. The roles of the sea surface temperature (SST) in the Indian Ocean and the Pacific are not yet discussed, for example, the cooler than observed SST in the Indian Ocean and the South China Sea may influence the onset and strength of the EASM, the SST bias in the Northwest Pacific may have an impact on the Philippine anticyclone that is important to the EASM. These biases may be amplified at a different climate background, therefore, a further study of model's biases are needed.

\section{Supplementary material related to this article is available online at: http://www.clim-past.net/9/453/2013/ cp-9-453-2013-supplement.pdf.}

Acknowledgements. We sincerely thank the two anonymous reviewers for their comments and suggestions on the discussion of this manuscript. We acknowledge the World Climate Research Programme's Working Group on Coupled Modelling, which is responsible for CMIP, and we thank the climate modelling groups (listed in Table 1 of this paper) for producing and making available their model output. For CMIP the US Department of Energy's 
Programme for Climate Model Diagnosis and Intercomparison provides coordinating support and led development of software infrastructure in partnership with the Global Organisation for Earth System Science Portals. The PMIP3 and PMIP2 Data archives are supported by CEA and CNRS. More information is available at http://pmip3.1sce.ipsl.fr. This study is jointly supported by the Chinese National Basic Research Program (Grant Nos. 2012CN955202 and 2010CB950502), the "Strategic Priority Research Program Climate Change: Carbon Budget and Relevant Issues" of the Chinese Academy of Sciences (Grant No. XDA05110301), the National Natural Science Foundation (Grant Nos. 41006008 and 41023002) and the National Key Technologies R\&D Programme project (Grant No. 2010AA012302).

Edited by: M. Crucifix

\section{References}

Bao, Q., Lin, P., Zhou, T., Liu, Y., Yu, Y., Wu, G., He, B., He, J., Li, L., Li, J., Li, Y., Liu, H., Qiao, F., Song, Z., Wang, B., Wang, J., Wang, P., Wang, X., Wang, Z., Wu, B., Wu, T., Xu, Y., Yu, H., Zhao, W., Zheng, W., and Zhou, L.: The Flexible Global OceanAtmosphere-Land System model, Spetral Version 2: FGOALSs2, Adv. Atmos. Sci., doi:10.1007/s00376-012-2113-9, in press, 2013.

Bartlein, P., Harrison, S., Brewer, S., Connor, S., Davis, B., Gajewski, K., Guiot, J., Harrison-Prentice, T., Henderson, A., Peyron, O., Prentice, I., Scholze, M., Seppä, H., Shuman, B., Sugita, S., Thompson, R., Viau, A., Williams, J., and Wu, H.: Pollenbased continental climate reconstructions at 6 and $21 \mathrm{ka}$ : a global synthesis, Clim. Dynam., 37, 775-802, doi:10.1007/s00382-0100904-1, 2011.

Berger, A.: Long-Term Variations of Daily Insolation and Quaternary Climatic Changes, J. Atmos. Sci., 35, 2362-2367, doi:10.1175/1520-0469(1978)035<2362:Itvodi >2.0.co;2, 1978.

Braconnot, P., Marti, O., Joussaume, S., and Leclainche, Y.: Ocean Feedback in Response to $6 \mathrm{kyr}$ BP Insolation, J. Climate, 13, 1537-1553, doi:10.1175/15200442(2000)013<1537:ofirtk>2.0.co;2, 2000.

Braconnot, P., Otto-Bliesner, B., Harrison, S., Joussaume, S., Peterchmitt, J.-Y., Abe-Ouchi, A., Crucifix, M., Driesschaert, E., Fichefet, Th., Hewitt, C. D., Kageyama, M., Kitoh, A., Laîné, A., Loutre, M.-F., Marti, O., Merkel, U., Ramstein, G., Valdes, P., Weber, S. L., Yu, Y., and Zhao, Y.: Results of PMIP2 coupled simulations of the Mid-Holocene and Last Glacial Maximum Part 1: experiments and large-scale features, Clim. Past, 3, 261277, doi:10.5194/cp-3-261-2007, 2007a.

Braconnot, P., Otto-Bliesner, B., Harrison, S., Joussaume, S., Peterchmitt, J.-Y., Abe-Ouchi, A., Crucifix, M., Driesschaert, E., Fichefet, Th., Hewitt, C. D., Kageyama, M., Kitoh, A., Loutre, M.-F., Marti, O., Merkel, U., Ramstein, G., Valdes, P., Weber, L., Yu, Y., and Zhao, Y.: Results of PMIP2 coupled simulations of the Mid-Holocene and Last Glacial Maximum Part 2: feedbacks with emphasis on the location of the ITCZ and mid- and high latitudes heat budget, Clim. Past, 3, 279-296, doi:10.5194/cp-3-279-2007, 2007b.
Collier, M. A., Jeffrey, S. J., Rotstayn, L. D., Wong, K. K., Dravitzki, S. M., Moseneder, C., Hamalainen, C., Syktus, J. I., Suppiah, R., Antony, J., El Zein, A., and Artif, M.: The CSIROMk3.6.0 Atmosphere-Ocean GCM: participation in CMIP5 and data publication, International Congress on Modelling and Simulation - MODSIM 2011, The 19th International Congress on Modelling and Simulation (MODSIM2011) was held at the Perth Convention and Exhibition Centre in Perth, 12-16 December 2011, Perth, Western Australia, 2011.

Ding, Y. H. and Chan, J. C. L.: The East Asian summer monsoon: an overview, Meteorol. Atmos. Phys., 89, 117-142, doi:10.1007/s00703-005-0125-z, 2005.

Dufresne, J.-L., Foujols, M.-A., Denvil, S., Caubel, A., Marti, O., Aumont, O., Balkanski, Y., Bekki, S., Bellenger, H., Benshila, R., Bony, S., Bopp, L., Braconnot, P., Brockmann, P., Cadule, P., Cheruy, F., Codron, F., Cozic, A., Cugnet, D., de Noblet, N., Duvel, J.-P., Ethé, C., Fairhead, L., Fichefet, T., Flavoni, S., Friedlingstein, P., Grandpeix, J.-Y., Guez, L., Guilyardi, E., Hauglustaine, D., Hourdin, F., Idelkadi, A., Ghattas, J., Joussaume, S., Kageyama, M., Krinner, G., Labetoulle, S., Lahellec, A., Lefebvre, M.-P., Lefevre, F., Levy, C., Li, Z. X., Lloyd, J., Lott, F., Madec, G., Mancip, M., Marchand, M., Masson, S., Meurdesoif, Y., Mignot, J., Musat, I., Parouty, S., Polcher, J., Rio, C., Schulz, M., Swingedouw, D., Szopa, S., Talandier, C., Terray, P., and Viovy, N.: Climate change projections using the IPSL-CM5 Earth System Model: from CMIP3 to CMIP5, Clim. Dynam., in revision, 2012.

Folland, C. K., Rayner, N. A., Brown, S. J., Smith, T. M., Shen, S. S. P., Parker, D. E., Macadam, I., Jones, P. D., Jones, R. N., Nicholls, N., and Sexton, D. M. H.: Global temperature change and its uncertainties since 1861, Geophys. Res. Lett., 28, 26212624, doi:10.1029/2001g1012877, 2001.

Fu, C. B., An, Z. S., Wu, X. D., and Wang, M. X.: Past climate changes over China, in: Global change researches in China, Beijing,, Global change researches in China, edited by: Ye, D. Z. and Chen, B. Q., China Earthquake Press, Beiing, 1992.

Gent, P. R., Danabasoglu, G., Donner, L. J., Holland, M. M., Hunke, E. C., Jayne, S. R., Lawrence, D. M., Neale, R. B., Rasch, P. J., Vertenstein, M., Worley, P. H., Yang, Z.-L., and Zhang, M.: The Community Climate System Model Version 4, J. Climate, 24, 4973-4991, doi:10.1175/2011jcli4083.1, 2011.

Giorgetta, M. A., Jungclaus, J., Reick, C., Stevens, B., Marotzke, J., Claussen, M., Roeckner, E., Mauritsen, T., Crueger, T., Schmidt, H., Manzini, E., Esch, M., Rast, S., Kinne, S., Zhang, K., Kornblueh, L., Haak, H., Segschneider, J., Six, K., Raddatz, T., Gayler, V., Schnur, R., Legutke, S., Widmann, H., and Glushak, K.: Climate variability and climate change in MPI-ESM CMIP5 simulations, J. Adv. Model. Earth Syst., in revision, 2012.

Gordon, C., Cooper, C., Senior, C. A., Bamks, H., Gregory, J. M., Johns, T. C., Mitchell, J. F. B., and Wood, R. A.: The simulation of SST, sea ice extents and ocean heat transport in a version of the Hadley Centre coupled model without flux adjustments, Clim. Dynam., 16, 147-168, 2000.

IPCC: Climate Change 2007: the Physical Science Basis, in: Contribution of Working Group I to the Fourth Assessment Report of the Intergovernmental Panel on Climate Change, edited by: Solomon, S., Qin, D., Manning, M., Chen, Z., Marquis, M., Averyt, K. B., Tignor, M., and Miller, H. L., Cambridge University Press, Cambridge, UK and New York, NY, USA, 2007. 
Jacob, R., Schafer, C., Foster, I., Tobis, M., and Anderson, J.: Computational Design and Performance of the Fast Ocean Atmosphere Model, Version One, in: Proc. 2001 International Conference on Computational Science, edited by: Alexandrov, V. N., Dongarra, J. J., and Tan, C. J. K., Springer-Verlag, 175-184., 2001.

Jiang, D. B., Wang, H. J., and Lang, X. M.: Evaluation of East Asian climatology as simulated by seven coupled models, Adv. Atmos. Sci., 22, 479-495, 2005.

Jiang, D. B., Lang, X., Tian, Z., and Wang, T.: Considerable Model ÄiData Mismatch in Temperature over China during the MidHolocene: Results of PMIP Simulations, J. Climate, 25, 41354153, doi:10.1175/jcli-d-11-00231.1, 2012.

Joussaume, S., Taylor, K. E., Braconnot, P., Mitchell, J. F. B., Kutzbach, J. E., Harrison, S. P., Prentice, I. C., Broccoli, A. J., Abe Ouchi, A., Bartlein, P. J., Bonfils, C., Dong, B., Guiot, J., Herterich, K., Hewitt, C. D., Jolly, D., Kim, J. W., Kislov, A., Kitoh, A., Loutre, M. F., Masson, V., McAvaney, B., McFarlane, N., de Noblet, N., Peltier, W. R., Peterschmitt, J. Y., Pollard, D., Rind, D., Royer, J. F., Schlesinger, M. E., Syktus, J., Thompson, S., Valdes, P., Vettoretti, G., Webb, R. S., and Wyputta, U.: Monsoon changes for 6000 years ago: Results of 18 simulations from the Paleoclimate Modelling Intercomparison Project (PMIP), Geophys. Res. Lett., 26, 859-862, doi:10.1029/1999g1900126, 1999.

Jungclaus, J., Keenlyside, N., Botzet, M., Haak, H., Luo, J., Latif, M., Marotzke, J., Mikolajewicz, U., and Roeckner, E.: Ocean circulation and tropical variability in the coupled model ECHAM5/MPI-OM, J. Climate, 19, 3952-3972, 2006.

K-1 model developers: K-1 Coupled GCM (MIROC) description, K-1 Tech. Rep. 1, Center for Climate System Research (CCSR), University of Tokyo, National Institute for Environmental Studies (NIES), Frontier Research Center for Global Change (FRCGC), 34 pp., 2004.

Kalnay, E., Kanamitsu, M., Kistler, R., Collins, W., Deaven, D., Gandin, L., Iredell, M., Saha, S., White, G., Woollen, J., Zhu, Y., Leetmaa, A., Reynolds, R., Chelliah, M., Ebisuzaki, W., Higgins, W., Janowiak, J., Mo, K. C., Ropelewski, C., Wang, J., Jenne, R., and Joseph, D.: The NCEP/NCAR 40-year reanalysis project, B. Am. Meteorol. Soc., 77, 437-470, 1996.

Li, L., Lin, P., Yu, Y., Wang, B., Zhou, T., Liu, L., Liu, J., Xu, S., Huang, W., Xia, K., Pu, Y., Dong, L., Shen, S., Liu, Y., Hu, N., Liu, M., Sun, W., Shi, X., Zheng, W., Wu, B., Song, M., Liu, H., Zhang, X., Wu, G., Xue, W., Huang, X., Yang, G., Song, Z., and Qiao, F.: The Flexible Global Ocean-Atmosphere-Land System Model: Grid-point Version g2: FGOALS-g2, Adv. Atmos. Sci., doi:10.1007/s00376-012-2140-6, in press, 2013.

Marsland, S. J., Haak, H., Jungclaus, J. H., Latif, M., and Röske, F.: The Max-Planck-Institute global ocean/sea ice model with orthogonal curvilinear coordinates, Ocean Model., 5, 91-127, doi:10.1016/S1463-5003(02)00015-X, 2003.

Marti, O., Braconnot, P., Dufresne, J. L., Bellier, J., Benshila, R., Bony, S., Brockmann, P., Cadule, P., Caubel, A., Codron, F., de Noblet, N., Denvil, S., Fairhead, L., Fichefet, T., Foujols, M. A., Friedlingstein, P., Goosse, H., Grandpeix, J. Y., Guilyardi, E., Hourdin, F., Idelkadi, A., Kageyama, M., Krinner, G., Lévy, C., Madec, G., Mignot, J., Musat, I., Swingedouw, D., and Talandier, C.: Key features of the IPSL ocean atmosphere model and its sensitivity to atmospheric resolution, Clim. Dynam., 34, 1-26, doi:10.1007/s00382-009-0640-6, 2010.

Mitchell, T. D. and Jones, P. D.: An improved method of constructing a database of monthly climateobservations and associated high-resolution grids, Int. J. Climatol., 25, 693-712, 2005.

Ni, J., Yu, G., Harrison, S. P., and Prentice, I. C.: Palaeovegetation in China during the late Quaternary: Biome reconstructions based on a global scheme of plant functional types, Palaeogeogr. Palaeocl., 289, 44-61, doi:10.1016/j.palaeo.2010.02.008, 2010.

Otto-Bliesner, B., Brady, E., Clauzet, G., Tomas, R., Levis, S., and Kothavala, Z.: Last glacial maximum and Holocene climate in CCSM3, J. Climate, 19, 2526-2544, 2006.

Phipps, S. J.: The CSIRO Mk3L Climate System Model, Technical Report No. 3, Antarctic Climate \& Ecosystems CRC, Hobart, Tasmania, Australia, 236 pp., 2006.

Prentice, I. C., Jolly, D., and BIOME 6000 Participants: MidHolocene and glacial-maximum vegetation geography of the northern continents and Africa, J. Biogeogr., 27, 507-519, doi:10.1046/j.1365-2699.2000.00425.x, 2000.

Renssen, H., Goosse, H., Fichefet, T. V. B., Driesschaert, E., and Wolk, F.: Simulating the Holocene climate evolution at northern high latitude using a coupled atmosphere-sea ice-oceanvegetation model, Clim. Dynam., 24, 23-43, 2005.

Schmidt, G. A., Ruedy, R., Hansen, J. E., Aleinov, I., Bell, N., Bauer, M., Bauer, S., Cairns, B., Canuto, V., Cheng, Y., Del Genio, A., Faluvegi, G., Friend, A. D., Hall, T. M., Hu, Y., Kelley, M., Kiang, N. Y., Koch, D., Lacis, A. A., Lerner, J., Lo, K. K., Miller, R. L., Nazarenko, L., Oinas, V., Perlwitz, J., Perlwitz, J., Rind, D., Romanou, A., Russell, G. L., Sato, M., Shindell, D. T., Stone, P. H., Sun, S., Tausnev, N., Thresher, D., and Yao, M.S.: Present-Day Atmospheric Simulations Using GISS ModelE: Comparison to In Situ, Satellite, and Reanalysis Data, J. Climate, 19, 153-192, 2006.

Shi, P. J. and Song, C. Q.: Palynological records of environmental changes in the middle part of Inner Mongolia, China, Chin. Sci. Bull., 48, 1433-1438, 2003.

Shi, Y. F., Kong, Z. Z., Wang, S. M., Tang, L. Y., Wang, F. B., Yao, T. D., Zhao, X. T., Zhang, P. Y., and Shi, S. H.: Mid-Holocene climates and enviroments in China, Global Planet. Change, 7, 219-233, 1993.

Song, Z., Qiao, F., and Song, Y.: Response of the equatorial basin-wide SST to wave mixing in a climate model: An amendment to tropical bias, J. Geophys. Res., 117, C00J26, doi:10.1029/2012JC007931, 2012.

Sun, Q. L., Zhou, J., Shen, J., Chen, P., Wu, F., and Xie, X. P.: Environmental characteristics of Mid-Holocene recorded by lacustrine sediments from Lake Daihai, north environment sensitive zone, China, Sci. China Ser. D, 49, 968-981, 2006.

Tang, L. Y., Shen, C. M., Liu, K., and Overpeck, J. T.: Changes in South Asian monsoon: new high-resolution paleoclimatic records from Tibet, China, Chin. Sci. Bull., 45, 87-91, 2000.

Tao, S. Y. and Chen, L. X.: A review of recent research on the East Asian summer monsoon in China, Monsoon Meteorology, edited by: Chang, C. P. and Krishnamurti, T. N., Oxford Univ. Press, New York, 60-92, 1987.

Voldoire, A., Sanchez-Gomez, E., Salas y Mélia, D., Decharme, B., Cassou, C., Sénési, S., Valcke, S., Beau, I., Alias, A., Chevallier, M., Déqué, M., Deshayes, J., Douville, H., Fernandez, E., Madec, G., Maisonnave, E., Moine, M. P., Planton, S., SaintMartin, D., Szopa, S., Tyteca, S., Alkama, R., Belamari, S., 
Braun, A., Coquart, L., and Chauvin, F.: The CNRM-CM5.1 global climate model: description and basic evaluation, Clim. Dynam., 1-31, doi:10.1007/s00382-011-1259-y, 2012.

Wang, B., Bao, Q., Hoskins, B., Wu, G., and Liu, Y.: Tibetan Plateau warming and precipitation changes in East Asia, Geophys. Res. Lett., 35, L14702, doi:10.1029/2008g1034330, 2008.

Wang, T., Wang, H. J., and Jiang, D. B.: Mid-Holocene East Asian summer climate as simulated by the PMIP2 models, Palaeogeogr. Palaeocl. 288, 93-102, 2010.

Wu, G., Liu, Y., Zhang, Q., Duan, A., Wang, T., Wan, R., Liu, X., Li, W., Wang, Z., and Liang, X.: The Influence of Mechanical and Thermal Forcing by the Tibetan Plateau on Asian Climate, J. Hydrometeorol., 8, 770-789, doi:10.1175/jhm609.1, 2007.

Wu, T.: A Mass-Flux Cumulus Parameterization Scheme for Largescale Models: Description and Test with Observations, Clim. Dynam., 38, 725-744, doi:10.1007/ s00382-011-0995-3, 2012.

Xie, P. P. and Arkin, P. A.: Global precipitation: A 17-year monthly analysis based on gauge observations, satellite estimates, and numerical model outputs, B. Am. Meteorol. Soc., 78, 2539-2558, 1997.

Yao, T. D., Xie, Z. C., Wu, X. L., and Thompson, L. G.: Climatic change since little Ice Age recored by Dundle Ice Cap, Sci. China Ser. B, 34, 760-767, 1991.

Yin, Q. Z. and Berger, A.: Insolation and $\mathrm{CO}_{2}$ contribution to the interglacial climate before and after the Mid-Brunhes Event, Nat. Geosci., 3, 243-246, 2010.

Yin, Q. Z. and Berger, A.: Individual contribution of insolation and $\mathrm{CO}_{2}$ to the the interglacial climates of the past 800,000 years, Clim. Dynam., 38, 709-724, doi:10.1007/s00382-011-1013-5, 2012.

Yu, G., Prentice, I. C., Harrision, S. P., and Sun, X.: Pollen-based biome reconstructions for China at 0 and 6000 years, J. Biogeogr., 25, 1055-1069, 1998.

Yu, G., Chen, X., Ni, J., Cheddadi, R., Guiot, J., Han, H., Harrison, S. P., Huang, C., Ke, M., Kong, Z., Li, S., Li, W., Liew, P., Liu, G., Liu, J., Liu, Q., Liu, K. B., Prentice, I. C., Qui, W., Ren, G., Song, C., Sugita, S., Sun, X., Tang, L., Van Campo, E., Xia, Y.,
Xu, Q., Yan, S., Yang, X., Zhao, J., and Zheng, Z.: Palaeovegetation of China: a pollen data-based synthesis for the midHolocene and last glacial maximum, J. Biogeogr., 27, 635-664, doi:10.1046/j.1365-2699.2000.00431.x, 2000.

Yu, Y., Zhang, X. H., and Guo, Y. F.: Global coupled oceanatmosphere general circulation models in LASG/IAP, Adv. Atmos. Sci., 21, 444-455, 2004.

Yukimoto, S., Noda, A., Kitoh, A., Hosaka, M., Yoshimura, H., Uchiyama, T., Shibata, K., Arakawa, O., and Kusunoki, S.: Present-Day Climate and Climate Sensitivity in the Meteorological Research Institute Coupled Gcm Version 2.3 (Mri-Cgcm2.3), J. Meteorol. Soc. Jpn., 84, 333-363, 2006.

Yukimoto, S., Adachi, Y., Hosaka, M., Sakami, T., Yoshimura, H., Hirabara, M., Tanaka, T. Y., Shindo, E., Tsujino, H., Deushi, M., Mizuta, R., Yabu, S., Obata, A., Nakano, H., Ose, T., and Kitoh, A.: A new global climate model of Meteorological Research Institute: MRI-CGCM3 - Model description and basic performance, J. Meteorol. Soc. Jpn., 90a, 23-64, 2012.

Zhao, Y., Braconnot, P., Marti, O., Harrison, S. P., Hewitt, C., Kitoh, A., Liu, Z., Mikolajewicz, U., Otto-Bliesner, B., and Weber, S. L.: A multi-model analysis of the role of the ocean on the African and Indian monsoon during the mid-Holocene, Clim. Dynam., 25, 777-800, doi:10.1007/s00382-005-0075-7, 2005.

Zhao, Z. C., Ding, Y. H., Li, X. D., and Wang, S. W.: Evaluation of CGCM climate simulation in East Asian region, J. Appl. Meteorol., 6, 9-18, 1995.

Zheng, W. and Braconnot, P.: Characterization of model spread in PMIP2 mid-Holocene simulations of the African Monsoon, J. Climate, doi:10.1175/JCLI-D-12-00071.1, in press, 2012.

Zheng, W. and Yu, Y.: The Asian Monsoon System of the midHolocen simulated by a coupled GCM, Quaternary Sci., 29, 1135-1145, 2009.

Zheng, W. and Yu, Y.: Paleoclimate simulations of the midHolocene and Last Glacial Maximum by FGOALS, Adv. Atmos. Sci., doi:10.1007/s00376-012-1177-x, in press, 2013. 